\title{
Renal tubular acidosis presenting with muscle weakness
}

\author{
DESMOND CARROLL AND PAGET DAVIES
}

From the Departments of Neurology and Cardiology, King's College Hospital, London

Muscle weakness is a common neurological symptom but is rarely due to hypokalaemia consequent on renal disease, as in the patients reported here. Two types of acidosis occur in renal disease. The more common and unfortunately incurable is that complicating chronic renal failure. Less common, but since it is treatable, more important, is renal tubular acidosis. That described by Lightwood (1935) presents during infancy, while the second is diagnosed only during adult life because of its complications (Albright, Burnett, Parson, Reifenstein, and Roos, 1946). Smith (1960), reviewing the clinical signs of the disorder in 28 adults, of whom $70 \%$ were females, found that $50 \%$ had osteomalacia, $70 \%$ renal calculi, $75 \%$ nephrocalcinosis, while $45 \%$ showed evidence of hypokalaemia. The same year, Owen and Verner (1960) were able to describe nine patients with renal tubular acidosis who presented with muscle weakness due to hypokalaemia. They could find only 13 other examples described previously in the literature, but emphasized nevertheless the importance of making the diagnosis and instituting appropriate therapy as soon as possible.

We have had the opportunity to observe two women in whom severe muscle weakness consequent upon hypokalaemia was the presenting feature of renal tubular acidosis. Both patients responded completely to a simple alkali mixture.

\section{CASE REPORTS}

CASE 1 A woman aged 45 was admitted to hospital on 19 December 1961 with a history of attacks of muscle weakness for five years and constant fatigue and loss of weight for two years. The attacks were precipitated by warm weather, except for the last which necessitated her admission to hospital. The first attack lasted about two weeks, but each succeeding episode had tended to last for a longer period of time. For about five weeks she had complained of parasthesiae in the face and hands and double vision. She had become drowsy, very thirsty, and was passing large quantities of urine. Her previous illnesses and family history were not relevant.

On examination, the patient was drowsy, dehydrated, and had obviously lost weight. She was confused and disorientated in place and time. The fundi, fields of vision, and cranial nerves showed no abnormality. In the limbs there was a moderate degree of wasting and weakness, which was particularly evident in the proximal muscles. The tendon reflexes were present and the plantar responses were flexor in type. There was no sensory loss. General examination was normal, the blood pressure being $110 / 70 \mathrm{~mm} . \mathrm{Hg}$.

Laboratory investigations The main biochemical and haematological data are summarized in Table I. The blood cells were morphologically normal while the corrected E.S.R. (Wintrobe) was $10 \mathrm{~mm}$. per $100 \mathrm{~mm}$. in the first hour. The serum proteins were $7.5 \mathrm{~g}$. per $100 \mathrm{ml}$., and on electrophoresis the gamma globulin fraction was increased, while the plasma alkaline phosphatase was 7 units per $100 \mathrm{ml}$. The urine contained a moderate amount of protein but no Bence-Jones protein, reducing substance, excess of amino-acids, or porphyrins. An occasional leucocyte was present but no organisms were cultured. The $p \mathrm{H}$ of the urine was 7 and after ingestion of ammonium chloride fell only to 6.7 although the alkali reserve fell to $3.5 \mathrm{mEq}$. per litre. The excretion of calcium in the urine was $100 \mathrm{mg}$. during a period of 24 hours. The electrocardiogram showed a PR interval

TABLE I

BIOCHEMICAL AND HAEMATOLOGICAL DATA IN CASE 1

\begin{tabular}{|c|c|c|c|c|c|c|c|c|}
\hline Date & $\begin{array}{l}\text { Sodium } \\
(m E q . / l .)\end{array}$ & $\begin{array}{l}\text { Chloride } \\
(m E q . / l .)\end{array}$ & $\begin{array}{l}\text { Potassium } \\
\text { (mEq./l.) }\end{array}$ & $\begin{array}{l}\text { Bicarbonate } \\
(m E q . / l .)\end{array}$ & $\begin{array}{l}\text { Urea } \\
\text { (mg./100 ml.) }\end{array}$ & $\begin{array}{l}\text { Calcium } \\
(\mathrm{mg} . / 100 \mathrm{ml} .)\end{array}$ & $\begin{array}{l}\text { Phosphorus } \\
(\mathrm{mg} . / 100 \mathrm{ml} .)\end{array}$ & $\begin{array}{l}\text { Haemoglobin } \\
(\mathrm{g} . / 100 \mathrm{ml} .)\end{array}$ \\
\hline Dec. 1961 & $\begin{array}{l}136 \\
126 \\
134\end{array}$ & $\begin{array}{r}109 \\
105 \\
-\end{array}$ & $\begin{array}{l}1 \cdot 5 \\
2 \cdot 7 \\
3 \cdot 8\end{array}$ & $\begin{array}{l}5 \\
13 \\
-\end{array}$ & $\begin{array}{l}85 \\
46 \\
-\end{array}$ & $\begin{array}{l}8 \cdot 8 \\
-\end{array}$ & $\begin{array}{l}2 \cdot 2 \\
-\end{array}$ & $\begin{array}{c}11.4 \\
-\end{array}$ \\
\hline Jan. 1962 & 138 & 106 & $2 \cdot 8$ & 16 & 49 & - & 一 & $10 \cdot 7$ \\
\hline Feb. 1962 & 138 & 107 & $3 \cdot 8$ & $\begin{array}{l}23 \\
5\end{array}$ & 36 & 8.9 & 2.9 & $12 \cdot 3$ \\
\hline
\end{tabular}




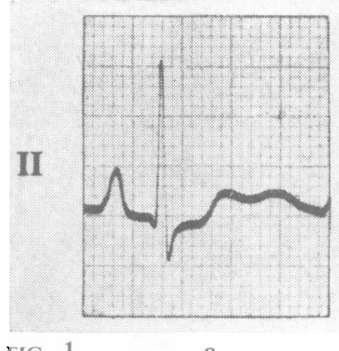

FIG. 1 a

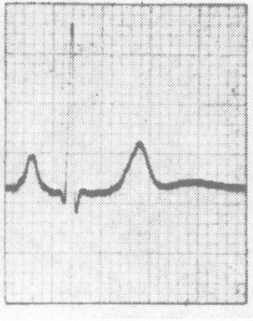

b
FIG. 1. Lead II of the electrocardiogram (a) showing a $P R$ interval of 0.20 second, depression of the $S T$ segment, and a prominent $U$ wave due to hypokalaemia (serum potassium $1.5 \mathrm{mEq}$. per litre), and (b) after recovery (serum potassium $2.7 \mathrm{mEq}$. per litre).

FIG. 2. Electro-encephalogram, showing (a) bilateral high amplitude delta activity with a generalized low amplitude polyrhythmia (serum potassium $1.5 \mathrm{mEq}$. per litre), and (b) after recovery (serum potassium $2.7 \mathrm{mEq}$. per litre).

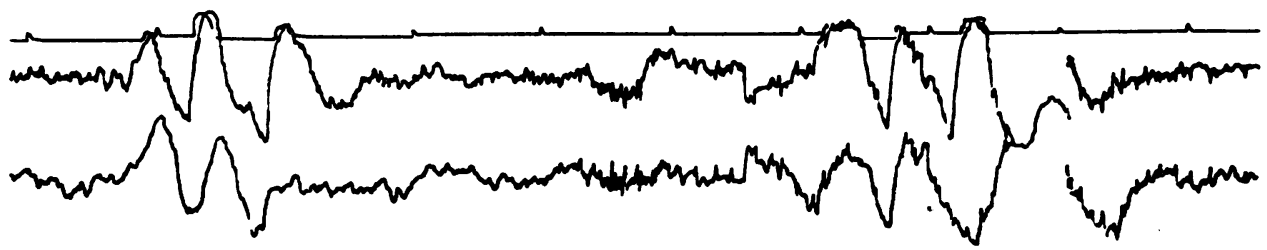

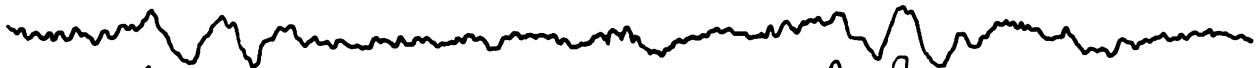

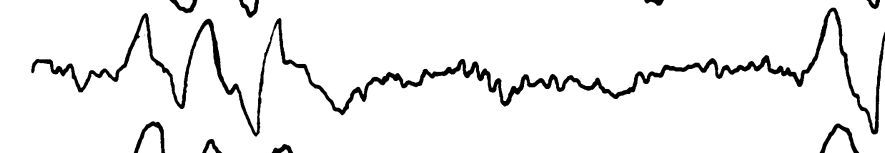

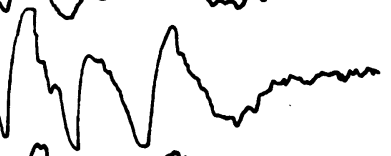

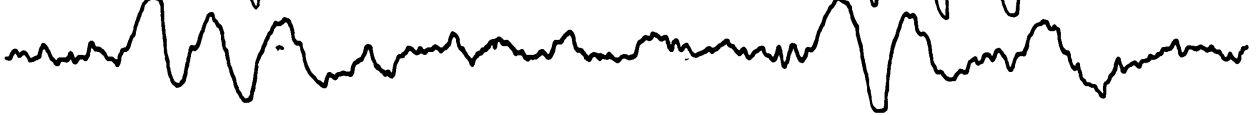

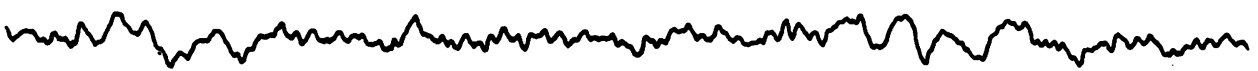

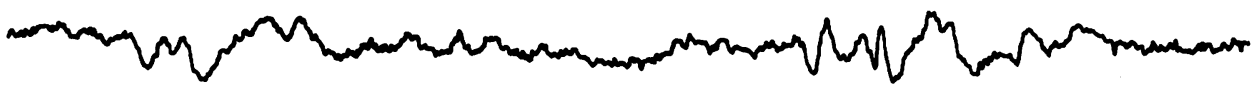

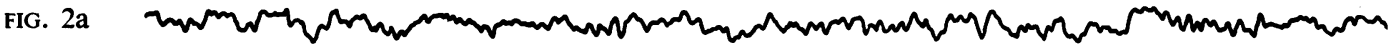

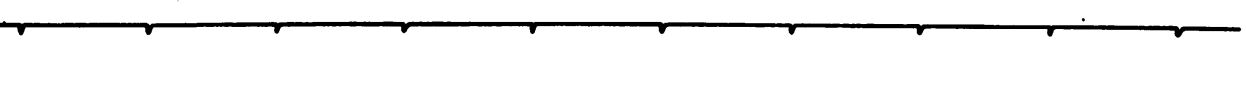

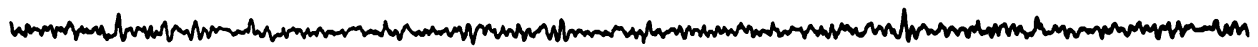

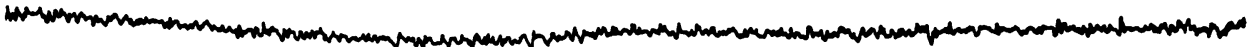

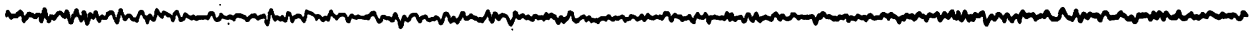

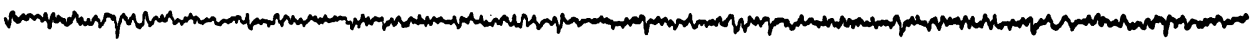

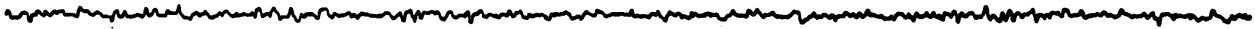

FIG. $2 b$ 


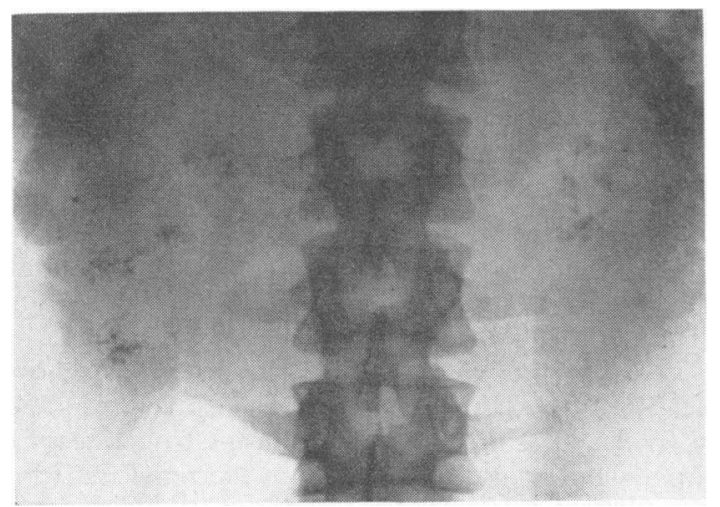

FIG. 3. Straight radiograph of the abdomen, showing nephrocalcinosis.

of 0.20 of a second, widespread ST segment depression, and prominent $U$ waves (Fig. 1a). An electromyogram was normal. An electroencephalogram showed a mixture of theta and beta rhythms and high amplitude paroxysmal bilateral delta activity (Fig. 2a). A straight radiograph of the abdomen showed bilateral nephrocalcinosis but intravenous pyelography demonstrated normal excretion in both kidneys (Fig. 3).

Treatment and progress These clinical findings indicated renal tubular acidosis complicated by hypokalaemia and nephrocalcinosis. An alkali mixture, consisting of potassium citrate $3 \mathrm{~g}$. and sodium bicarbonate $3 \mathrm{~g}$., was given daily. Within a week, the patient was able to walk and after six weeks she had recovered completely. The serum electrolytes were now normal (Table I). Progress was complicated by an attack of tetany which responded satisfactorily to intravenous calcium gluconate. In addition, she developed impairment of vision in the right eye due to a central scotoma. It was accompanied by a headache without vomiting or sensory disturbance. The visual defect resolved rapidly and it was thought to be migrainous in origin. The electroencephalogram was repeated and on this occasion there was no abnormality present.

CASE 2 A woman aged 58, who was a retired 'child actress', was admitted to hospital on 27 May 1958 with a history of intermittent but progressive muscle weakness and loss of weight of three months' duration. The weak- ness had become so extreme that she was completely incapacitated. In October 1951, a hysterectomy had been performed for fibroids, the cervix being noted to be very small. Six months later she had presented with a tuberculous abscess in the right sacro-iliax joint, which healed completely after a year. There was no relevant family history.

On examination, the patient was emaciated, dehydrated, and very weak. Intellectual function was not impaired. The fundi, fields of vision, and cranial nerves showed no abnormality. In the limbs, there was a considerable degree of wasting and weakness which was particularly evident in the proximal muscles. The tendon reflexes were present and the plantar responses were flexor in type. There was no sensory loss. General examination was normal, the blood pressure being $170 / 70 \mathrm{~mm}$. $\mathrm{Hg}$.

Laboratory investigations The main biochemical and haematological data are summarized in Table II. The erythrocytes showed rouleaux formation while the corrected E.S.R. (Wintrobe) was $41 \mathrm{~mm}$. per $100 \mathrm{~mm}$. in the first hour. The serum proteins were $7.6 \mathrm{~g}$. per $100 \mathrm{ml}$. and on electrophoresis the gamma globulin was increased, while the plasma alkaline phosphatase was 15 units per $100 \mathrm{ml}$. The urine contained a moderate amount of protein but no Bence-Jones protein, reducing substance, or excess of amino-acids. Numerous white cells were present and coliform organisms were cultured. The $p \mathrm{H}$ of the urine was 6.8 and after ingestion of ammonium chloride fell only to $5 \cdot 8$, although the alkali reserve fell to $9 \mathrm{mEq}$. per litre. During 24 hours, the excretion of calcium in the urine was $65 \mathrm{mg}$. The glomerular filtration rate was $53 \mathrm{ml}$. per minute per $1.72 \mathrm{~m}^{2}$ and urinary phosphate threshold $1 \mathrm{mg}$. per minute per $1.73 \mathrm{~m}^{2}$. A chest radiograph showed no abnormality in the heart or lungs but multiple fractures of the ribs were present.

Treatment and progress These clinical findings indicated renal tubular acidosis complicated by hypokalaemia and osteomalacia. An alkali mixture, consisting of citric acid $6 \mathrm{~g}$., sodium citrate $3 \mathrm{~g}$., and potassium citrate $3 \mathrm{~g}$., was given daily to correct the electrolyte imbalance. Within a month, the patient was able to walk and the serum electrolytes were normal (Table II). Two months later she was discharged from hospital but continued to take the alkali mixture. The fractures of the ribs healed while the serum electrolyte levels remained normal. However, the raised sedimentation rate and serum gamma globulin persisted.

In March 1959, she was found to be anaemic with a haemoglobin level of $8.9 \mathrm{~g}$. per $100 \mathrm{ml}$. Examination of

TABLE II

BIOCHEMICAL AND HAEMATOLOGICAL DATA IN CASE 2

\begin{tabular}{|c|c|c|c|c|c|c|c|c|}
\hline Date & $\begin{array}{l}\text { Sodium } \\
(m E q . / l .)\end{array}$ & $\begin{array}{l}\text { Chloride } \\
(m E q . / l .)\end{array}$ & $\begin{array}{l}\text { Potassium } \\
(m E q . / l .)\end{array}$ & $\begin{array}{l}\text { Bicarbonate } \\
(m E q . / l .)\end{array}$ & $\begin{array}{l}\text { Urea } \\
(\mathrm{mg.} / 100 \mathrm{ml} .)\end{array}$ & $\begin{array}{l}\text { Calcium } \\
(\mathrm{mg} . / 100 \mathrm{ml} .)\end{array}$ & $\begin{array}{l}\text { Phosphorus } \\
\text { (mg./100 ml.) }\end{array}$ & $\begin{array}{l}\text { Haemoglobin } \\
(\mathrm{g} . / 100 \mathrm{ml} .)\end{array}$ \\
\hline June 1958 & 133 & 114 & $3 \cdot 2$ & 14.5 & 48 & $7 \cdot 9$ & 0.9 & $12 \cdot 4$ \\
\hline July 1958 & 130 & 114 & 3.9 & 21 & 54 & - & - & - \\
\hline Aug. 1958 & 135 & 104 & $4 \cdot 4$ & 22 & 45 & $8 \cdot 3$ & $3 \cdot 2$ & - \\
\hline Mar. 1959 & 130 & 101 & $4 \cdot 1$ & 22 & 47 & 8.9 & $4 \cdot 5$ & 8.9 \\
\hline May 1960 & 133 & 103 & $4 \cdot 6$ & 23 & 39 & $9 \cdot 0$ & $3 \cdot 2$ & 13.9 \\
\hline June 1961 & 132 & 104 & $4 \cdot 1$ & 23 & 37 & - & $2 \cdot 8$ & 13.9 \\
\hline June 1962 & 130 & 103 & 3.7 & 23 & 34 & $8 \cdot 5$ & $2 \cdot 5$ & $13 \cdot 5$ \\
\hline
\end{tabular}


the erythrocytes confirmed that the anaemia was of the hypochromic type. The serum iron was $20 \mu \mathrm{g}$. per $100 \mathrm{ml}$. and the bone marrow showed micronormoblastic erythropoiesis, but no excess of plasma cells. Leucopoiesis was normal. Examination of the stools was negative for occult blood. After three months' treatment by iron taken orally, the haemoglobin rose to $13.9 \mathrm{~g}$. per $100 \mathrm{ml}$. and the anaemia did not recur.

In July 1961, the blood pressure was found to be $240 / 140 \mathrm{~mm}$. Hg. The chest radiograph did not show any evidence of left ventricular enlargement while the electrocardiogram was within normal limits. Guanethidine, $25 \mathrm{mg}$. daily, was given and the blood pressure fell to $250 / 105 \mathrm{~mm}$. Hg. Even so, in December 1961, a small left macular haemorrhage occurred but subsequently resolved.

A year later, in February 1963, following influenza, she developed a staphylococcal pneumonia with renal failure (Table II). Initially her condition responded to ampicillin and cortisone therapy with intravenous fluids. However, in March 1963 she suffered a myocardial infarction complicated by hypotension and a resultant cerebral sinus thrombosis. Four days later she died. Unfortunately permission for necropsy was refused.

\section{DISCUSSION}

The pathogenesis of renal tubular acidosis is due probably to hydrogen ions not being exchanged either actively or passively for sodium ions. As a result, an excess of bicarbonate is excreted in an insufficiently acid urine. Since the anions produced by metabolism are excreted in the urine accompanied by increased excretion of sodium, potassium, and calcium, hyponatraemia, hypokalaemia, and hypocalcaemia with acidosis result. Hyperchloraemia also occurs due to shrinkage of the extracellular space from sodium loss. Ammonium excretion may be so high, however, that nephrocalcinosis may occur in the absence of acidosis and only after administration of ammonium chloride may acidosis be revealed. Although hydrogen ions are produced by the action of carbonic anhydrase, no one has yet demonstrated any defect in this enzyme either by using acetozolamide (Webster, Huth, Elkinton, and McCance, 1960) or by biopsy of the kidney (Yaffe, Craig, and Fellers, 1960). Thus the fundamental biochemical defect is still unknown.

Although renal tubular acidosis presenting in infancy is regarded as having a high rate of recovery, it is possible in some patients that the disease may progress and as a result of complications be diagnosed only in adult life. The second patient may be such an example since she showed failure of growth and sexual maturation and a similar patient who was a dwarf has been reported by Foss, Perry, and Wood (1956). Huth, Webster, and Elkinton (1960), reviewing 162 examples of renal tubular acidosis, have suggested that the disease in the infantile form may be transmitted by a recessive gene, and in the late adult group, by an autosomal dominant gene, most evident in female subjects. While the disorder in infancy may be associated with various inborn 0 errors of metabolism, such as glycosuria and aminoaciduria in the de Toni-Fanconi syndrome, Huth and his colleagues could find little evidence to incriminate pyelonephritis as a cause, and indeed Randall and Targgart (1961) regarded it as a complication.

Muscle weakness was the dominant presenting feature in both patients and was related to hypok- $\overrightarrow{0}$ alaemia. Of course, this may result from excessive 흠 loss of potassium not only from the renal but from the gastro-intestinal tract or even redistribution of the $\overparen{\nabla}$ cation within the cells. The hypokalaemia occurred insidiously in the two patients. In the first patient, it had fluctuated, had even resulted in diplopia and was reflected in the electrocardiogram and electroencephalogram. Of interest was the rapid response of both patients to an increase in the intake of potassium. Parasthesiae were noted in the first $\frac{7}{0}$ patient before potassium was given and afterwards tetany resulted, which responded promptly to calciurn gluconate given intravenously. The mechanism of the ir tetany is unknown but Fourman (1954) has bees 을 unable to relate it to an increased intracellulap concentration of potassium.

The electro-encephalographic findings in the firs patient were particularly interesting. At the firg recording, the patient was semiconscious, confuses and unable to obey any but the simplest commands $\overrightarrow{5}$

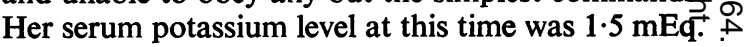
per litre. The resting encephalogram showed bilateral high amplitude delta activity, but maximal in both frontal regions, arising from a generalized polyrhythmic background of much lower amplitude. The record resembled that of a patient deeply asleep (Fig. 2a). Within a few seconds of hyperventilation, the patient became restless, more confused, and incontinent of urine, and the test had to be abandoned. The probable explanation for this immediate change is that a further deficit in the level of the serum potassium occurred which exacerbated the symptoms already present.

Three days later the encephalogram was repeated. On this occasion, she was sitting up, fully aware of all that was going on, able to converse in a normal fashion, and interested in all the proceedings. She had no recollection of having had an electroencephalogram previously. No specific treatment had $\rightarrow$ been given her, and her clinical improvement was thought to be due to a spontaneous recovery, the N cause for which was as yet unknown. The serum potassium level at this time was $2.7 \mathrm{mEq}$. per litre $\tilde{N}$ and the electrocardiogram and electro-encephalo- 
gram were now within normal limits (Figs. 1b and 2b).

By chance, it was discovered that on two occasions during the previous three days, she had eaten in all approximately $6 \mathrm{oz}$. of stewed figs. Figs contain $143 \mathrm{mg}$. of potassium per ounce and it seemed that the figs could have been responsible for the patient's apparently 'spontaneous' recovery.

The mechanism of the changes in the electroencephalogram is difficult to evaluate. Reduction in the level of potassium results in a failure of transmission of the nerve impulse at synaptic junctions which could, in turn, cause generalized intermittent slowing of electrical activity throughout the cortex.

The treatment of renal tubular acidosis consists of correcting the electrolytic abnormalities, preventing any further loss of cations in the urine, and eradicating any renal infection. The dosage of the alkali mixture is variable and should be regulated by frequent estimations of the serum electrolytes.

The prognosis is uncertain, for while both patients responded to treatment, this is not curative. Thus the first patient, although no longer uraemic, has developed nephrocalcinosis. The second patient developed hypertension, presumably due to pyelonephritis, itself a complication of the renal tubular acidosis.
SUMMARY

Two adult patients are described in whom muscle weakness due to hypokalaemia was the presenting feature of renal tubular acidosis.

Attention is drawn to the electrocardiographic and electro-encephalographic features of hypokalaemia.

Our thanks are due to Dr. S. Nevin and Dr. J. L. Livingstone for permission to publish the case reports. We wish to thank Mrs. D. Butcher for the electroencephalographic recordings and the Photographic Department for the illustrations.

\section{REFERENCES}

Albright, F., Burnett, C. H., Parson, W., Reifenstein, E. C. Jr., and Roos, A. (1946). Medicine (Baltimore), 25, 399.

Foss, G. L., Perry, C. B., and Wood, F. J. Y. (1956). Quart. J. Med., 25,185 .

Fourman, P. (1954). Lancet, 2, 525.

Huth, E. J., Webster, G. D. Jr., and Elkinton, J. R. (1960). Amer. J. Med., 29, 586.

Lightwood, R. (1935). Arch. Dis. Childh., 10, 205.

Owen, E. E., and Verner, J. V. Jr. (1960). Amer. J. Med., 28, 8.

Randall, R. E. Jr., and Targgart, W. H. (1961). Ann. intern. Med., 54, 1108.

Smith, L. H. Jr. (1960). In The Metabolic Basis of Inherited Disease, edited by J. B. Stanbury, J. B. Wyngaarden, and D. S. Fredrickson, p. 1256. McGraw-Hill, New York.

Webster, G. D. Jr., Huth, E. J., Elkinton, J. R., and McCance, R. A. (1960). Amer. J. Med., 29, 576.

Yaffe, S. J., Craig, J. M., and Fellers, F. X. (1960). Amer. J. Med., 29 168. 